\title{
Preparation and Characterization of Mucoadhesive Loratadine Nanoliposomes for Intranasal Administration
}

\author{
İntranazal Uygulama için Mukoadhesif Loratadin Nanolipozomlarının \\ Hazırlanması ve Karakterizasyonu
}

\author{
(D) Lena TAMADDON¹, (D) Negar MOHAMADI ${ }^{1}$, (D) Neda BAVARSAD1,2* \\ 1Department of Pharmaceutics, Faculty of Pharmacy, Ahvaz Jundishapur University of Medical Sciences, Ahvaz, Iran \\ 2Nanotechnology Research Center, Ahvaz Jundishapur University of Medical Sciences, Ahvaz, Iran
}

\begin{abstract}
Objectives: The present study aimed to formulate and characterize mucoadhesive liposomes for intranasal delivery of loratadine. In particular, the formulation was aimed to improve the drug bioavailability and efficacy.

Materials and Methods: Liposomes were prepared by thin-film hydration method, with soybean phosphatidylcholine and cholesterol as main components. Liposomes were coated with chitosan solution at a concentration of $0.05 \%$ and $0.1 \%, \mathrm{w} / \mathrm{v}$. The formulations were assessed for particle size, polydispersity index (PDI), encapsulation efficiency (EE), thermodynamic behavior, in vitro drug release, mucoadhesiveness, and stability.

Results: Particle size analysis showed that the vesicles of uncoated and coated liposomes with $0.05 \%$ and $0.1 \%$ chitosan were characterized by size of $193 \pm 3.3 \mathrm{~nm}, 345 \pm 4.6$, and $438 \pm 7.3 \mathrm{~nm}$, respectively. Size distribution for developed formulations was in the acceptable range (PDI $<0.7$ ). EE was recorded to be approximately $80 \%$. Chitosan-coated liposomes demonstrated slower release rate as compared to uncoated liposomes. Drug release kinetics profile for all the formulations followed a zero-order model. Chitosan coating improved mucoadhesiveness by more than 3 -fold as compared to uncoated liposomes. However, no significant differences were recorded between mucin adsorption behavior of $0.05 \%$ and $0.1 \%$ chitosan-coated liposomes ( $p>0.05$ ). For stability studies, liposomes were stored at $4^{\circ} \mathrm{C}$ for 3 months, and changes in particle diameter, PDI, and EE $\%$ were recorded. No significant alternations were reported in particles size, PDI, and drug leakage of coated liposomes.

Conclusion: Liposomes coated with $0.05 \%$ chitosan were chosen as the optimum formulation, which demonstrated a significant potential for overcoming the nasal drug delivery limits for short residence time and mucociliary clearance.
\end{abstract}

Key words: Liposomes, loratadine, mucoadhesive, chitosan, intranasal

ÖZ

Amaç: Bu çalışma, ilaç biyoyararlanımını ve etkinliğini artırmak için loratadin mukoadhesif burun içi lipozomlarını formüle etmek ve değerlendirmeyi amaçlamaktadır. Özellikle, formülasyon ilaç biyoyararlanımını ve efikasitesini geliştirmeyi hedeflemiştir.

Gereç ve Yöntemler: Lipozomlar, ana bileșenler olarak soya fasulyesi fosfatidilekolin ve kolesterol kullanılarak ince film hidrasyon yöntemiyle hazırlanmıştır. Lipozomlar, \%0,05 ve \%0,1 a/h konsantrasyonda kitosan çözeltisi ile kaplanmıştır. Formülasyonlar partikül boyutu, polidispersite indeksi (PDI), kapsülleme etkinliği (EE), termodinamik davranışları, in vitro ilaç salımı, mukoadhesiviteleri ve stabilite açısından değerlendirilmiștir.

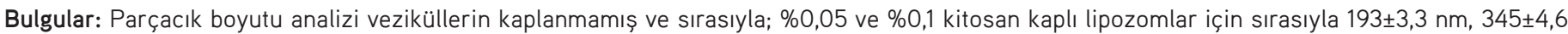
ve $438 \pm 7,3 \mathrm{~nm}$ boyutlarında elde edildiğini göstermiştir. Geliștirilen tüm formülasyonlar için boyut dağılımı için kabul edilebilir ranjda bulunmuştur (PDI $\langle 0,7)$. EE yaklaşık \%80 civarında kaydedilmiștir. Kitosan kaplanmış aplanmış lipozomlar, kaplanmamış olanlara kıyasla daha yavaş salım oranı göstermiștir. İlaç salım kinetik modeli, tüm formülasyonlar için sıfır derece modeli göstermiștir. Kitosan kaplama, kaplanmamış lipozomlara kıyasla mukoadhesiviteyi 3 kattan fazla artırmıștır. Ancak, \%0,05 ve \%0,1 kitosan kaplama müsin adsorpsiyon davranışında arasında anlamlı bir fark kadedilmemiștir (p>0,05). Stabilite çalışmaları için, lipozomlae $4^{\circ} \mathrm{C}^{\prime}$ de üç aylık depolanmıș ve partikül boyutu, PDI ve \%EE'deki değișiklikler kaydedilmiştir. Partikül boyutu, PDI ve kaplı lipozomlardan ilaç sızıntısı konularında belirgin değişiklikler olmadığı raporlanmıştır.

Sonuç: \%0,05 ile kaplanan lipozomlar kısa kalma süresinin ve mukosiliyer klerensinin nazal ilaç verme sınırlarının üstesinden gelmek için önemli bir potansiyel gösterebilen optimum formülasyon olarak seçilmiștir.

Anahtar kelimeler: Lipozomlar, loratadin, mukoadhesif, kitosan, intranazal 


\section{INTRODUCTION}

Allergic rhinitis (AR) is an inflammation of the nasal mucosa, caused by the exposure to allergens. Generally, it involves four primary symptoms, namely sneezing, rhinorrhea, nasal congestion, and nasal itching.1.2 Most commonly prescribed medications for the treatment of AR include antihistamines, corticosteroids, and decongestants.

Loratadine is a long lasting second generation antihistamine, which is widely used in the treatment and management of various allergic disorders, such as rhinitis, urticarial, and upper respiratory tract infections. ${ }^{3}$ Despite its fast absorption post oral administration, loratadine suffers from issue of poor oral bioavailability (40\%), primarily owing to first-pass metabolism. In addition to this, loratadine has been previously shown to induce certain systemic side effects in the body, after oral administration. In particular, loratadine is associated with allergic reactions that involve rash, itching, difficulty in breathing, tightness in the chest, swelling of the mouth or face, and dizziness. ${ }^{4}$ Thus, it is important to explore and utilize another route of administration to bypass the liver metabolism and overcome these systemic side effects.

Intranasal drug delivery appears to be a convenient and interesting route as it confers several advantages. In particular, it provides ample applicable area for improving the systemic absorption of drugs with low solubility. ${ }^{5}$ The presence of highly vascularized sub-epithelial layer in the nasal membrane allows rapid onset of drug action. Additionally, this route bypasses first-pass metabolism, and ensures higher bioavailability of drugs even at lower doses. ${ }^{6,7}$ However, the process of mucociliary clearance in this area as a defense mechanism against foreign particles acts as the major limitation of the intranasal route. In particular, this phenomena can lead to complete removal of the drug delivery system from the nasal cavity. ${ }^{8}$

Among the various nasal drug delivery systems, liposomes have been widely explored for both local and systemic purposes. Liposomes are phospholipid bilayer vehicles that confer several advantages, including biocompatibility, biodegradability, and targeted drug delivery. Additionally, liposomal drug delivery prevents enzymatic or chemical degradation of drugs. ${ }^{910}$ Interestingly, coating of liposomes using mucoadhesive polymers might increase their drug residence time in the nasal cavity, and thus improve drug bioavailability.

Chitosan, a natural cationic polymer produced by deacetylation of chitin, can act as a mucoadhesive agent for drug delivery systems, which is mediated via electrostatic interactions with the negative charge of mucin in the nasal cavity. Thus, the use of chitosan assists in improving the overall residence time of the liposomes that further leads to an enhancement in drug bioavailability and permeation."

The present study aimed to formulate mucoadhesive liposomes for intranasal delivery of loratadine, which could circumvent the first-pass hepatic metabolism and enhance the drug bioavailability.

\section{MATERIALS AND METHODS}

\section{Materials}

Loratadine was received as a kind gift from Shafa ${ }^{\circledR}$ Pharmaceutical Co. (Tahran, Iran). Cholesterol, chitosan, periodic acid, Schiff reagent, and dialysis tubing cellulose membrane were procured from Sigma-Aldrich (St. Louis, Missouri, United States of America). Soybean phosphatidylcholine was purchased from Lipoid GmbH (Ludwigshafen, Germany). Chloroform, methanol, acetic acid, sodium acetate tri-hydrate, and sodium monobasic and dibasic phosphate were acquired from Merck Co. (Darmstadt, Germany). All the chemicals used in the study were of analytical grade.

\section{Preparation of liposomes}

Liposomes were prepared using a thin film hydration method. Briefly, soybean phosphatidylcholine and cholesterol at a molar ratio of $7: 4$ and $100 \mathrm{mg}$ loratadine were dissolved in $20 \mathrm{~mL}$ mixture of chloroform:methanol (volume ratio 2:1). Following this, the solvent was evaporated at $50^{\circ} \mathrm{C}$, using a rotary evaporator (IKA RV05), until a thin film was formed. The resulting film was incubated at $4^{\circ} \mathrm{C}$ for $24 \mathrm{~h}$ in a refrigerator, to ensure complete evaporation of the solvent. After $24 \mathrm{~h}$, the thin film was hydrated using 20 $\mathrm{mL}$ phosphate buffer ( $\mathrm{pH}: 6.5$ ) and agitated using ultrasonic bath (ELMA, t-710 DH) for $30 \mathrm{~min}$ at $50^{\circ} \mathrm{C}$. For the production of chitosan-coated liposomes, chitosan solutions at the concentrations of $0.1 \%$ and $0.05 \% \mathrm{w} / \mathrm{v}$ (in $0.1 \% \mathrm{v} / \mathrm{v}$ acetic acid) were added drop wise into the liposomal suspension with continuous stirring for $1 \mathrm{~h}$. Further, the mixtures were centrifuged at $15,000 \mathrm{rpm}$ for $45 \mathrm{~min}$ at $20^{\circ} \mathrm{C}$ and the sediments were resuspended in phosphate buffer $(\mathrm{pH}: 6.5)$ at room temperature using a vortex, to achieve a homogeneous preparation. ${ }^{12}$

\section{Loratadine encapsulation efficiency (EE)}

For the calculation of $\mathrm{EE}$, the liposomal suspension was centrifuged at $15,000 \mathrm{rpm}$ for $30 \mathrm{~min}$, at $20^{\circ} \mathrm{C}$. Further, the resulting supernatant was analyzed using ultraviolet (UV) spectroscopy (WPA biowave2) at $249 \mathrm{~nm}$. EE was determined using following equation: ${ }^{13}$

$\%$ Encapsulation $=($ Total amount of loratadine - amount of loratadine in the supernatant) $\times 100 \% /$ (total amount of loratadine)

\section{Particle size and polydispersity index (PDI) analysis}

The average particle size of the formulation was determined using Scatterscope 1, Qudix (Seoul, South Korea). Prior to the measurement, the liposomal suspension was diluted using filtered deionized water ( 1 to 20 ). Each sample was read in triplicates.

\section{Differential scanning calorimetry (DSC)}

DSC thermogram was recorded for lipids, chitosan, and the drug using DSC 1 METTLER TOLEDO Co. Certain amount of the samples was placed in an aluminum pan and scanned from $20^{\circ} \mathrm{C}-200^{\circ} \mathrm{C}$, at a scanning rate of $10^{\circ} \mathrm{C} \mathrm{min}^{-1}$. 
In vitro drug release studies

In vitro release profile for loratadine was evaluated using dialysis bag diffusion technique, in a dissolution apparatus dt800 ERWEKA Co. (Germany). Briefly, dialysis bags (cutoff: $12 \mathrm{KDa}$ ) containing the formulations were placed in baskets, and immersed into the flasks containing $300 \mathrm{~mL}$ of the release medium. The release medium comprised of a mixture of acetate buffer (pH:5.5) and methanol at a ratio of 50:50, v/v. The temperature and rotation speed for the baskets were set at $37^{\circ} \mathrm{C}$ and $100 \mathrm{rpm}$, respectively. The sample collection was performed at pre-defined time intervals of $0.5,1,2,3,4,5,6$, and $24 \mathrm{~h}$. At each time point, $1 \mathrm{~mL}$ of sample was collected and replaced with $1 \mathrm{~mL}$ of fresh medium. Following this, amount of loratadine in the collected samples was analyzed using UV spectroscopy at $249 \mathrm{~nm}$. This test was performed in triplicates for each formulation. ${ }^{14}$

\section{Mucoadhesion test}

Mucoadhesive potential of the generated formulations was measured in terms of the adsorption of mucin (porcine stomach type II) by periodic acid/Schiff colorimetric method.15,16

Standard mucin solutions at the concentrations of $12.5,6.25$, 3.125, and $1.625 \mathrm{mg}$ per $100 \mathrm{~mL}$ of phosphate buffer ( $\mathrm{pH}: 5.5$ ) were prepared. Further, $200 \mu \mathrm{L}$ of periodic acid $(10 \%)$ was added to $2 \mathrm{~mL}$ of each sample. The samples were incubated at $37^{\circ} \mathrm{C}$ for $2 \mathrm{~h}$. Post incubation, $200 \mu \mathrm{L}$ of Schiff reagent was added to the mixtures, and UV absorbance was measured after $30 \mathrm{~min}$ at $555 \mathrm{~nm}$.

For samples, $1 \mathrm{~mL}$ of mucin solution $(0.125 \mathrm{mg} / \mathrm{mL})$ was added to $1 \mathrm{~mL}$ of the liposomal suspensions. Further, liposomes were stirred for $1 \mathrm{~h}$ at $37^{\circ} \mathrm{C}$ at $300 \mathrm{rpm}$. To determine the amount of free mucin, the samples were centrifuged at $15,000 \mathrm{rpm}$ for $45 \mathrm{~min}$ at $20^{\circ} \mathrm{C}$. Further, $200 \mu \mathrm{L}$ of periodic acid was added to the supernatants, and the samples were incubated at $37^{\circ} \mathrm{C}$ for $2 \mathrm{~h}$. Following this, $200 \mu \mathrm{L}$ of Schiff reagent was added. After 30 min of incubation, the absorbance was measured at $555 \mathrm{~nm}$ using a spectrophotometer.

\section{Stability study}

For the assessment of stability, the formulations were stored at $4^{\circ} \mathrm{C}$ for 3 months. The stability of the formulations was investigated in terms of particle size, PDI, and EE.

\section{Statistical analyses}

One-Way analysis of variance was used to compare the developed formulations. The multiple-comparison Tukey test was used to compare the mean values for different groups, and $p<0.05$ was considered statistically significant.

\section{RESULTS}

\section{Characterization of the liposomes}

In the present study, chitosan coated liposomal formulations were prepared and assessed for EE, particle size, and PDI. The results for all these parameters are summarized in Table 1. As shown in Table 1, the average size of nanoliposomes prior to the coating was recorded to be $193 \pm 3.3 \mathrm{~nm}$. The addition of chitosan as a coating on liposomes resulted in particles with increased size, wherein coating with $0.05 \%$ and $0.1 \%$ chitosan resulted in particles with size $345 \pm 4.6 \mathrm{~nm}$ and $438 \pm 7.3 \mathrm{~nm}$, respectively. Thus, coating process caused a significant increase in size of the particles ( $p<0.05$ ). Further, EE of $~ 80 \%$ was recorded for uncoated and coated formulations, which confirmed the suitability of preparation method and coating process.

\section{DSC thermogram}

The DSC thermograms for loratadine, cholesterol, chitosan, soybean phosphatidylcholine, uncoated liposomes, and liposomes with $0.05 \%$ chitosan were recorded (Figure 1a$f$, respectively). For loratadine, an endothermic peak was observed at $136^{\circ} \mathrm{C}$ in the DSC curve (Figure 1a), whereas two peaks were recorded at $46.30^{\circ} \mathrm{C}$ and $148.56^{\circ} \mathrm{C}$ for cholesterol (Figure 1b). In comparison to this, a broad endothermic peak was observed at $54.27^{\circ} \mathrm{C}$ for chitosan (Figure 1c). For phosphatidylcholine, an endothermic peak was recorded at $131^{\circ} \mathrm{C}$ (Figure 1d). The thermograms for uncoated (Figure 1e) and coated liposomes (Figure 1f) exhibited broad endothermic peak at $80^{\circ} \mathrm{C}-100^{\circ} \mathrm{C}$.

\section{In vitro drug release}

In vitro drug release profiles for the prepared liposomal formulations are shown in Figure 2. The drug release from the formulations was evaluated over a period of $24 \mathrm{~h}$. After $24 \mathrm{~h}$, maximum drug release of $99 \pm 0.03 \%$ was recorded for uncoated liposomes. For coated liposomes, a comparatively slow release rate was recorded, wherein liposomes coated with $0.05 \%$ and $0.1 \%$ chitosan displayed drug release of $94 \pm 0.05 \%$ and $81 \pm 0.02 \%$, respectively. Therefore, coating of liposomes provided a controllable drug release rate. The values for kinetics parameters and their regression are listed in Table 2. The selection of kinetics model was based on the higher value of $r^{2}$. In particular, zero-order model was found to be the most suitable kinetics model for all formulations, and chitosan coating showed no effect on kinetics model.

\section{Stability of formulations}

The results for stability study for the formulations, after 3 months of storage, are shown in Table 3. Interestingly, significant changes were recorded in case of uncoated liposomal formulation. Particularly, the size of the particles increased from $193 \mathrm{~nm}$ to $426 \mathrm{~nm}$, and PDI increased from 0.41 to 0.65 . In addition to this, EE reduced from $83 \%$ to $49 \%$. Importantly,

Table 1. Characteristics of different formulations (mean \pm SD, $n=3$ )

\begin{tabular}{llll} 
Formulations & $\begin{array}{l}\text { Encapsulation } \\
\text { efficiency }(\%)\end{array}$ & $\begin{array}{l}\text { Particle } \\
\text { size }(\mathrm{nm})\end{array}$ & PDI \\
\hline Uncoated liposomes & $83 \pm 4.3$ & $193 \pm 3.3$ & $0.41 \pm 0.05$ \\
\hline $\begin{array}{l}0.05 \% \text { chitosan-coated } \\
\text { liposomes }\end{array}$ & $78 \pm 4.6$ & $345 \pm 4.6$ & $0.54 \pm 0.08$ \\
\hline $\begin{array}{l}0.1 \% \text { chitosan-coated } \\
\text { liposomes }\end{array}$ & $81 \pm 3.9$ & $438 \pm 7.3$ & $0.69 \pm 0.03$ \\
\hline
\end{tabular}

SD: Standard deviation, PDI: Polydispersity index 

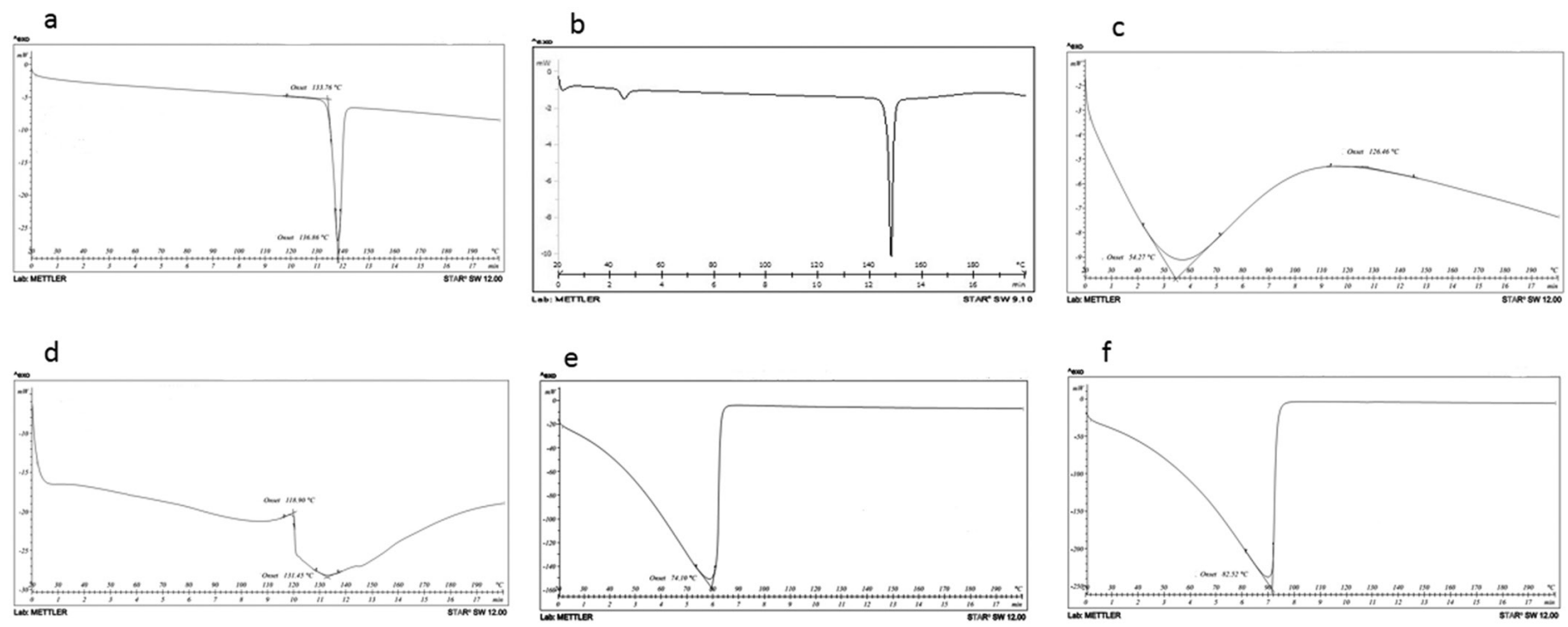

Figure 1. Differential scanning calorimetry thermograms for a) loratadine, b) cholesterol, c) chitosan, d) phosphatidylcholine, e) uncoated liposomes, and f) coated liposomes

coated formulations displayed no significant changes in the values of these parameters ( $p>0.05)$.

\section{Mucin adsorption study}

Chitosan is a polycationic polymer that interacts via electrostatic interactions with anionic groups present in the mucus layer, such as mucin. In particular, mucin is the most important component of mucus layer. The flexibility of chitosan backbone ensures ease of interaction between chitosan molecules and the mucus layer. ${ }^{17}$ Thus, the present study assessed mucin adsorption by nanoliposomes (uncoated

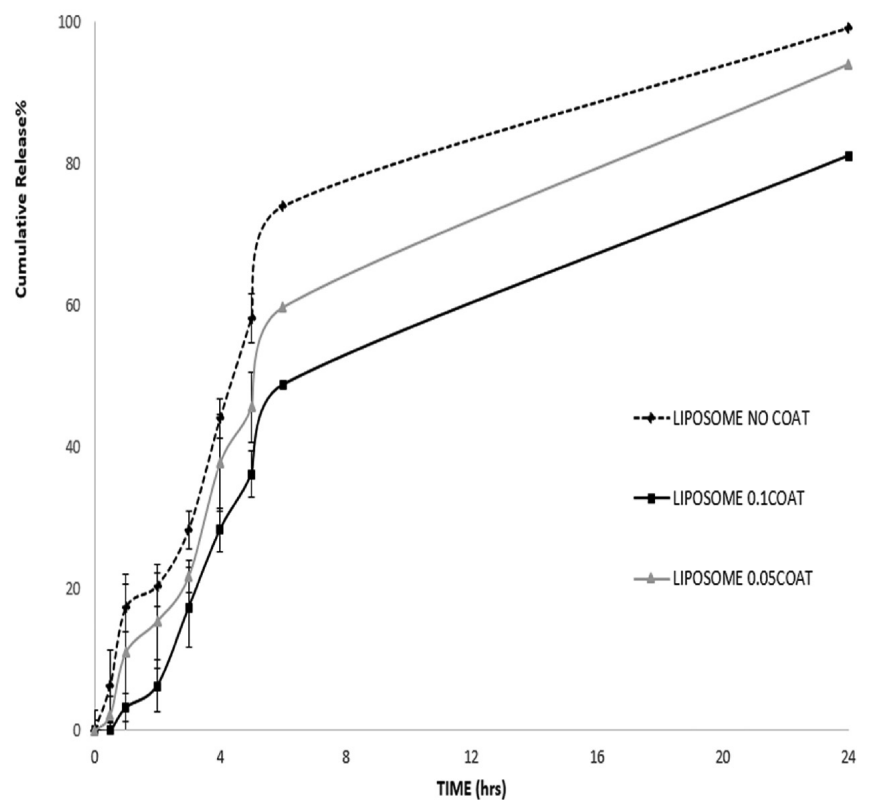

Figure 2. In vitro cumulative percentage of drug release expressed as a function of time (mean $\pm S D, n=3$ )

SD: Standard deviation and coated). As shown in Figure 3, chitosan-coated liposomes exhibiteda higher mucin adsorption, which was $>3$-folds higher as compared to uncoated liposomes. Interestingly, no significant differences were recorded for mucin adsorption behavior of the formulations coated with $0.05 \%$ and $0.1 \%$ chitosan ( $p>0.05$ ).

\section{DISCUSSION}

Loratadine is a long lasting second-generation antihistamine. It is lipophilic nature and belongs to class II Biopharmaceutical Classification System. Thus, it is characterized by low

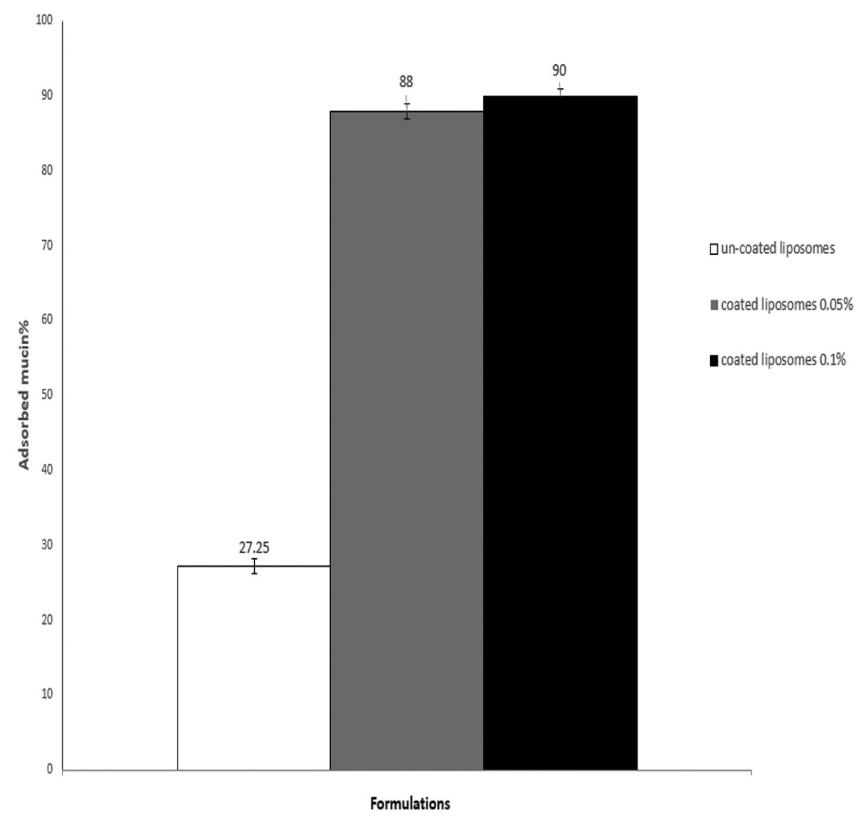

Figure 3. Mucoadhesive capacity of the formulations (expressed as percentage of mucin adsorbed, mean $\pm S D, n=3$ )

SD: Standard deviation 
Table 2. Drug release kinetics for the generated formulations

\begin{tabular}{lllll} 
& & \multicolumn{3}{c}{ Liposomal formulations } \\
\hline Kinetic model & Parameters & Uncoated & $\begin{array}{l}0.05 \% \\
\text { chitosan } \\
\text { coated }\end{array}$ & $\begin{array}{l}0.1 \% \\
\text { chitosan } \\
\text { coated }\end{array}$ \\
\hline \multirow{2}{*}{ Zero order } & $\mathrm{R}^{2}$ & 0.977 & 0.994 & 0.98 \\
& $\mathrm{~K}_{0}\left(\mathrm{mg} \mathrm{h}^{-1}\right)$ & 1.3994 & 1.1771 & 1.1398 \\
\hline \multirow{2}{*}{ Higuchi } & $\mathrm{R}^{2}$ & 0.8785 & 0.9113 & 0.9212 \\
& $\mathrm{~K}_{\mathrm{H}}\left(\mathrm{mg} \mathrm{cm}^{2} \mathrm{~h}^{-1}\right)$ & 3.4836 & 3.0972 & 3.5243 \\
\hline \multirow{2}{*}{ First order } & $\mathrm{R}^{2}$ & 0.9069 & 0.8326 & 0.9384 \\
& $\mathrm{~K}_{1}\left(\mathrm{~h}^{-1}\right)$ & -0.3905 & 0.4496 & 0.5556 \\
\hline \multirow{2}{*}{ Korsmeyer- } & $\mathrm{R}^{2}$ & 0.9566 & 0.976 & 0.9798 \\
Peppas & $\mathrm{K}$ & 1.546 & 1.0787 & 1.6027 \\
& $\mathrm{~N}$ & 0.9061 & 1.0997 & 1.6027 \\
\hline
\end{tabular}

Table 3. Characteristics of the formulations after 3 months of storage at $4^{\circ} \mathrm{C}$ (mean $\pm S D, n=3$ )

\begin{tabular}{llll} 
Formulations & $\begin{array}{l}\text { Encapsulation } \\
\text { efficiency }(\%)\end{array}$ & $\begin{array}{l}\text { Particle } \\
\text { size }(\mathrm{nm})\end{array}$ & PDI \\
\hline Uncoated liposomes & $49 \pm 6.6$ & $426 \pm 6.7$ & $0.65 \pm 0.06$ \\
\hline $\begin{array}{l}\text { 0.05\% chitosan- } \\
\text { coated liposomes }\end{array}$ & $71 \pm 3.8$ & $360 \pm 4.7$ & $0.59 \pm 0.09$ \\
\hline $\begin{array}{l}0.1 \% \text { chitosan-coated } \\
\text { liposomes }\end{array}$ & $72 \pm 8.1$ & $450 \pm 2.7$ & $0.73 \pm 0.07$ \\
\hline
\end{tabular}

SD: Standard deviation, PDI: Polydispersity index

solubility and high permeability. ${ }^{18}$ In the present study, different formulations of uncoated and coated liposomes loaded with loratadine were developed, and evaluated for intranasal administration. The results of the study showed that thin film hydration method provided a suitable method for successful preparation of liposomal preparation. All the developed formulations were characterized by submicron-sized vesicles, which exhibited acceptable stability and high EE. Importantly, coating of liposomes with chitosan resulted in a significant increase in the size of the particles.

The interaction between chitosan and liposomes could be attributed to a combination of adsorption coagulation and bridging between them. Interestingly, previous studies have provided evidences for hydrogen bonding between chitosan and the phospholipid head groups, and hydrophobic interaction between hydrophobic segments of chitosan and soybean phosphatidylcholine. ${ }^{19,20}$ The coating of liposomes with chitosan resulted in an increase in the mucoadhesive potential by more than 3-folds, which is suggestive of a significant potential for overcoming the nasal drug delivery limits for shorter residence time and mucociliary clearance. Mucoadhesive potential of chitosan-based delivery systems are mostly contributed by the presence of ionic interactions between the cationic primary amino groups of chitosan and the anionic substructures of the mucus. In addition to this, the hydrophobic interactions might also act as a contributing factor for this mucoadhesive potential. ${ }^{21}$
To study the interactions between various components and thermal events, DSC was performed. The DSC thermogram for loratadine showed an endothermic peak at $136^{\circ} \mathrm{C}$ that correlated with the melting point of the crystals. The thermogram for cholesterol first displayed a shallow endothermic peak at $46.30^{\circ} \mathrm{C}$ and an endothermic sharp peak at $148.56^{\circ} \mathrm{C}$, which are attributed to its melting point. Chitosan exhibited broad endothermic peak at $54.27^{\circ} \mathrm{C}$, which is related to the polymer phase transition from glassy to rubbery state. Phosphatidylcholine thermogram displayed a broad endothermic peak at $131^{\circ} \mathrm{C}$ that might be attributed to its physical change. In case of uncoated and coated liposomes, only a broad endothermic peak was observed at $80^{\circ} \mathrm{C}-100^{\circ} \mathrm{C}$, which was associated with evaporation of water. ${ }^{22}$ The disappearance of the components peak can be related to the interaction between the ingredients of liposome to form liposomal bilayer and appropriate encapsulation of loratadine inside this lipid bilayer. ${ }^{23}$ The results of the present study are consistent with the findings of previous studies. Alshweiat et al. ${ }^{24}$ investigated the nasal delivery of loratadine in a nanosuspension form, wherein DSC thermograms depicted a single endothermic peak at $135^{\circ} \mathrm{C}$ for loratadine. In comparison to this, the formulated loratadine showed a shifted peak with a reduced intensity, toward the lower melting point of loratadine. ${ }^{24}$ In another study, Singh et al..$^{25}$ investigated the nasal delivery of mucoadhesive in situ gel of loratadine, and the disappearance of characteristic endothermic peak of loratadine in this formulation was described in terms of inclusion of loratadine into the formulated preparation. Similar to present study, only a broad peak for water loss was detected in case of this complex.

The coating of liposomes with chitosan showed a significant effect on the drug release rate from liposomes, at different time intervals. As shown in Figure 2, the percentage of drug release from coated liposomes was lower as compared to uncoated liposomes, at all examined time intervals. This effect might be attributed chitosan mediated stabilization of the liposomal membrane by adherence to the surface, and formation of a coated layer that acts as a barrier against the release of drug from the surface. The data were analyzed using different fitting models for controlled release mechanisms. Interestingly, the models of controlled release mechanisms for liposomes coated with chitosan were found to be in agreement with the release behavior of uncoated liposomes. ${ }^{20,26}$

Stability studies for the formulations showed that coated liposomes exhibited little but non-significant changes in the size and PDI, over a period of 3 months. Therefore, in addition to mucoadhesiveness, coating of the liposomes improved their shelf life also.

In the view of insignificant effects of high concentration of chitosan coating on the mucoadhesiveness of the loratadine loaded liposomes and negative effects of high concentration of chitosan on particle size and PDI of the formulations, liposomes coated with lower percentage of chitosan $(0.05 \%)$ was selected as the optimum formulation, intended to be used for the treatment of AR. To establish the efficacy of selected preparation, in vivo studies would be performed in future. 


\section{CONCLUSION}

The present study reported the development of chitosancoated liposomes, and the developed formulation was found to be a suitable delivery system for intranasal administration of loratadine. Chitosan-coated liposomes exhibited suitable release profile and improved mucoadhesiveness. In future, in vivo studies would be conducted to further establish the therapeutic efficacy of the developed formulation.

\section{ACKNOWLEDGMENTS}

This paper is issued from Pharm D thesis of Negar Mohamadi and financial support was provided by a grant $(\mathrm{N}-9608)$ from vice chancellor of research of Ahvaz Jundishapur University of Medical Sciences, Ahvaz, Iran.

Conflict of interest: The authors have no conflicts of interest to declare. The experiments were conducted in full compliance with local regulatory principles of ethics committee of Ahvaz Jundishapur University of Medical Sciences (Ethics code: IR.AJUMS.REC.1396.770).

\section{REFERENCES}

1. Greiner AN, Hellings PW, Rotiroti G, Scadding GK. Allergic rhinitis. Lancet. 2011;378:2112-2122.

2. Bousquet J, Khaltaev N, Cruz AA, Denburg J, Fokkens W, Togias A, Zuberbier T, Baena-Cagnani C, Canonica G, Van Weel C. Allergic rhinitis and its impact on asthma (aria). Allergy. 2008;63:8-160.

3. Kroll V, Nothofer B, Werdermann K. Allergic bronchial asthma treated with loratadine. Fortschr Med. 1993;111:76-78.

4. Borgaonkar P, Virsen T, Hariprasanna R, Najmuddin M. Formulation and in vitro evaluation of buccal tablets of loratadine for effective treatment of allergy. Int J Res Pharm Chem. 2011;1:551-559.

5. Üner M, Karaman EF, Aydoğmuş Z. Solid lipid nanoparticles and nanostructured lipid carriers of loratadine for topical application: Physicochemical stability and drug penetration through rat skin. Trop J Pharm Res. 2014;13:653-660.

6. Bitter $C$, Suter-Zimmermann $K$, Surber $C$. Nasal drug delivery in humans. In: C Surber, P Elsner, MA Farage, eds. Topical applications and the mucosa. Karger Publishers; 2011:20-35.

7. Davis SS. Delivery of peptide and non-peptide drugs through the respiratory tract. Pharm Sci Technol Today. 1999;2:450-456.

8. Singh AK, Singh A, Madhv NS. Nasal cavity, a promising transmucosal platform for drug delivery and research approaches from nasal to brain targetting. J Drug Deliv Ther. 2012;2:22-33.

9. Marttin E, Schipper NG, Verhoef JC, Merkus FW. Nasal mucociliary clearance as a factor in nasal drug delivery. Adv Drug Del Rev. 1998;29:13-38.

10. Romeo V, DeMeireles J, Sileno A, Pimplaskar H, Behl C. Effects of physicochemical properties and other factors on systemic nasal drug delivery. Adv Drug Del Rev. 1998;29:89-116.
11. Sharma A, Sharma US. Liposomes in drug delivery: Progress and limitations. Int J Pharm. 1997;154:123-140.

12. Mombeini M, Saki G, Khorsandi L, Bavarsad N. Effects of silymarinloaded nanoparticles on ht-29 human colon cancer cells. Medicina (Kaunas). 2018;54:1-9.

13. Kouchak M, Malekahmadi M, Bavarsad N, Saki Malehi A, Andishmand L. Dorzolamide nanoliposome as a long action ophthalmic delivery system in open angle glaucoma and ocular hypertension patients. Drug Dev Ind Pharm. 2018;44:1239-1242.

14. Bavarsad N, Kouchak M, Mohamadipour P, Sadeghi-Nejad B. Preparation and physicochemical characterization of topical chitosan-based film containing griseofulvin-loaded liposomes. J Adv Pharm Technol Res. 2016;7:91-98.

15. Kisel M, Kulik L, Tsybovsky I, Vlasov A, Vorob'Yov M, Kholodova E, Zabarovskaya Z. Liposomes with phosphatidylethanol as a carrier for oral delivery of insulin: studies in the rat. Int J Pharm. 2001;216:105-114.

16. Saladini B, Bigucci F, Cerchiara T, Gallucci MC, Luppi B. Microparticles based on chitosan/pectin polyelectrolyte complexes for nasal delivery of tacrine hydrochloride. Drug Deliv Trans Res. 2013;3:33-41.

17. Takeuchi $H$, Yamamoto $H$, Niwa $T$, Hino $T$, Kawashima $Y$. Enteral absorption of insulin in rats from mucoadhesive chitosan-coated liposomes. Pharm Res. 1996;13:896-901.

18. Rodriguez Amado JR, Prada AL, Duarte JL, Keita H, da Silva HR, Ferreira AM, Sosa EH, Carvalho JCT. Development, stability and in vitro delivery profile of new loratadine-loaded nanoparticles. Saudi Pharm J. 2017;25:1158-1168.

19. Refai $H$, Hassan $D$, Abdelmonem R. Development and characterization of polymer-coated liposomes for vaginal delivery of sildenafil citrate. Drug Deliv. 2017;24:278-288.

20. Mady MM, Darwish MM. Effect of chitosan coating on the characteristics of dppc liposomes. J Adv Res. 2010;1:187-191.

21. Jøraholmen MW, Vanić Ž, Tho I, Škalko-Basnet N. Chitosan-coated liposomes for topical vaginal therapy: Assuring localized drug effect. Int J Pharm. 2014:472:94-101.

22. Merlusca IP, Matiut DS, Lisa G, Silion M, Gradinaru L, Oprea S, Popa IM. Preparation and characterization of chitosan-poly(vinyl alcohol)neomycin sulfate films. Polym Bull. 2018;75:3971-3986.

23. Zhai $B$, Wu $Q$, Wang $W$, Zhang $M$, Han $X$, Li Q, Chen $P$, Chen X, Huang X, Li G, Zhang Q, Zhang R, Xiang Y, Liu S, Duan T, Lou J, Xie T, Sui X. Preparation, characterization, pharmacokinetics and anticancer effects of pegylated $\beta$-elemene liposomes. Cancer Biol Med. 2020;17:60-75.

24. Alshweiat A, Csóka I, Tömösi $F$, Janáky T, Kovács A, Gáspár R, SztojkovIvanov A, Ducza E, Márki Á, Szabó-Révész P, Ambrus R. Nasal delivery of nanosuspension-based mucoadhesive formulation with improved bioavailability of loratadine: preparation, characterization, and in vivo evaluation. Int J Pharm. 2020;579:119166.

25. Singh RM, Kumar A, Pathak K. Thermally triggered mucoadhesive in situ gel of loratadine: B-cyclodextrin complex for nasal delivery. AAPS PharmSciTech. 2013;14:412-424.

26. Gibis M, Ruedt C, Weiss J. In vitro release of grape-seed polyphenols encapsulated from uncoated and chitosan-coated liposomes. Food Res Int. 2016;88:105-113. 